\title{
Designing Travel Aggregator Application Using the Integration of Fuzzy Electronic Service Quality and Fuzzy Refined Kano
}

\author{
Amanda Sucita Brahmana and Yati Rohayati \\ School of Industrial and System Engineering, Bandung, Indonesia \\ e-mail: amandabrahmana@student.telkomuniversity.ac.id
}

\begin{abstract}
The rapid development of transportation business makes travel aggregator application needed by the community. One diversified multinational company in Indonesia has developed a travel aggregator application to make customers easier to choose travel according to their needs. However, application design does not meet the standards proven by a preliminary survey. Therefore, it is necessary to explore the user's needs for travel aggregator application. This research aims to identify True Customer Needs by using the integration of Fuzzy Electronic Service Quality and Fuzzy Refined Kano in order to improve accuracy of data. To ensure the quality of the application before it is released, there are $8 \mathrm{key}$ dimensions of quality that used namely payment method, application design, ease of use, responsiveness, security \& privacy, information quality, portability, and maintainability. Fuzzy Electronic Service Quality is used to measure the level of satisfaction using the Fuzzy questionnaire. Fuzzy Refined Kano is used to obtain categories namely attractive $(A)$, must-be $(M)$, one-dimensional $(O)$, indifferent (I), reverse (R) and questionable $(Q)$ on each attribute need with Fuzzy processing. Based on the integration, there are 22 attributes need with 14 strong attributes need that need to be improved. The improved attributes need is called True Customer Needs.
\end{abstract}

Keywords-Travel Aggregator, True Customer Needs, Electronic Service Quality, Refined Kano and Fuzzy Logic.

\section{INTRODUCTION}

$\mathrm{T}$ HE rapid development of the transportation business makes people need a travel aggregator application. One of the multinational companies in Indonesia that provide technology based services and digital platforms, develops travel aggregator application to has ideal standard.

Travel aggregator is an application to facilitate people in getting information about travel agents such as travel agent options, prices, departure schedules, reviews and seats without wasting time searching for detailed information manually so many people in Indonesia use travel aggregator to make them easier to choose which travel agents that they need. The target of implementation of this travel aggregator application are to reach potential users, be able to maintain good relations with potential users in the long term, tickets can be booked easily, offer a large selection of travel agents and provide accurate information about travel agents. This causes an evaluation to be carried out to develop a travel aggregator application by conducting a preliminary study so that the application has specifications that fit the needs of the community.
The preliminary study in this research use depth interview with several participants who had used a competitor travel aggregator application. The depth interview stated as sufficient when the participants answer does not produce a new statement so that it is then summarized as Voice of Customer (VoC).

Based on Table I.1, it is necessary to develop an application to meet the ideal standards and be able to meet the needs of potential users so that they can compete with other travel aggregator applications in Indonesia that have retention and acquisition.

\section{A. Formulation of The Problem}

The method used to determine services that meet the needs of potential users in a travel aggregator application is integration between Fuzzy Electronic Service Quality [1] and Fuzzy Refined Kano (Lee \& Huang, 2009). Based on the model and the background that has been described, then the problem can be formulated for this research as follow:

1) What are the attribute needs of travel aggregator application based on the Electronic Service Quality dimensions?

2) How are the results of the measurement and classification the attribute needs of travel aggregator application based on the Electronic Service Quality dimensions?

3) How is the classification attribute needs of travel aggregator application based on the Fuzzy Refined Kano method?

4) What attributes of service requirements should be developed and prioritized in the travel aggregator application ?

5) What are the attributes that become True Customer Needs in the travel aggregator application?

B. Research Purposes

Based on the predetermined problem formulation, the objectives of this study are as follow:

1) Identifying the attribute needs of travel aggregator application based on the dimensions of Electronic Service Quality.

2) Measuring and classifying the attribute needs of the travel aggregator application based on the dimensions of Electronic Service Quality.

3) Determine the classification attribute needs of potential users who use a travel aggregator application based on the Fuzzy Refined Kano method. 
The $1^{\text {st }}$ International Conference on Business and Engineering Management (IConBEM)

February $1^{\text {st }} 2020$, Institut Teknologi Sepuluh Nopember, Surabaya, Indonesia

Table 1.

Participants Response Regarding Lack of The Travel Aggregator

\begin{tabular}{ll}
\hline \hline Lack of Competitor Travel Aggregator Applications & The Number of Complaints \\
\hline Application features are difficult to use. & 4 from 15 participants. \\
Application is difficult to understand. & 4 from 15 participants. \\
Application is difficult to access and operate. & 5 from 15 participants. \\
There is no promo feature. & 5 from 15 participants. \\
There is no explanation about the steps of payment method. & 5 from 15 participants. \\
Interface is not attractive and simple & 6 from 15 participants. \\
Cannot resolve error that slow down application performance. & 6 from 15 participants. \\
There is no refund and cancellation feature. & 6 from 15 participants. \\
There is no rescheduling feature. & 7 from 15 participants. \\
There is no clear information. & 8 from 15 participants. \\
Customer service is not responsive. & 10 from 15 participants. \\
\hline \hline
\end{tabular}

4) Determine what attributes that need to be developed and prioritized that related to services in the travel aggregator application.

5) Determine the attributes that become True Customer Needs in the travel aggregator application.

C. Scope of The Problem

This research has 2 scope of problem as follow :

1) Respondents from this study are people who have been using travel aggregators for six months with JakartaBandung/Bandung-Jakarta route and ordering through the application.

2) This research only define True Customer Needs.

\section{RESEARCH METHODOLOGY}

The research methodology defines how the research is carried out. This research starts with a statement of the problem and ends with a conclusion.

The conceptual model flow begins with the identification of customer needs attributes that have been classified in the form of Voice of Customer ( $\mathrm{VoC})$. $\mathrm{VoC}$ is obtained from potential users and users who have used the travel aggregator application for 6 months with Jakarta-Bandung or BandungJakarta route.

In the processing of Electronic Service Quality questionnaire with the integration of fuzzy models, the importance value is obtained to classify attribute needs into categories of strong and weak attributes. In processing the questionnaire data using the Fuzzy Kano model, functional and dysfunctional statements are obtained will be used to classify the attributes needs into attractive, must-be, onedimensional, indifferent, reverse and questionable categories. The results of the questionnaire processing will then be integrated with the Refined Kano dimensions : highly attractive, high value added, critical, potential, less attractive, low value-added, necessary and carefree for the recommendations.

\section{A. Preliminary Stage}

This stage is the initial stage of research by identifying the problems that occured in travel aggregator application and determining the methods used through literature studies and field studies. The method that used in this study is the integration of Fuzzy Electronic Service Quality and Fuzzy Refined Kano.

\section{1) Fuzzy Theory}

User needs can be assessed based on attributes and preferences, so that much uncertain information is contained.
There is a way to be able to manage this information using the Fuzzy theory that formulated by Professor Zadeh of the University of California at Berkeley (1965). The main contribution is being able to represent unclear data.

\section{2) Electronic Service Qualiy}

Electronic Service Quality is an important and key aspect to determine competitive advantage and factors in the long term retention of companies that operating online according to previous research and is a development of the Service Quality method to find out measurement dimensions that represent the performance and quality of the application.

Lack of quality-of-Service Quality such as software quality that compared to Electronic Service Quality is because Software Quality not explored transaction activities such as ordering and payment. Therefore, Software Quality cannot be categorized as an ideal measurement scale for electronic service quality.

The Electronic Service Quality Model cannot be fully generalized on all platforms such as using applications on various communication and updating the system when a system failure occurs. Therefore, users expect the application to be error free. To ensure the quality of the application before it is released, the dimensions need to be developed according to the topic of the problem. Because the topic of the problem is the development of a travel aggregator application, it is necessary to adjust the dimensions.

When combined with dimensions developed in accordance with the topic of the problem, there are 8 dimensions of namely ease of use, information, payment methods, application design, responsiveness, security and privacy, portability, and maintainability.

\section{3) Fuzzy Electronic Service Quality}

Electronic Service Quality is a combination of many attributes. There are subjective attributes such as security \& privacy that are difficult to measure accurately. The criticism for measuring Electronic Service Quality is that scores does not always represent the preferences of potential users. Respondents preferences often cannot be assessed with exact numericals. Therefore, previous research shows that Fuzzy is better able to reflect the true feelings of the respondents [2].

Fuzzy theory provides to present uncertainties and lack of information about certain elements. Integration between Electronic Service Quality methods by using the Fuzzy method to prevent uncertain individual views of the assessment of perceptions and expectations. 
The $1^{\text {st }}$ International Conference on Business and Engineering Management (IConBEM)

February $1^{\text {st }} 2020$, Institut Teknologi Sepuluh Nopember, Surabaya, Indonesia

Table 2 .

Results of Integration Fuzzy Electronic Service Quality and Fuzzy Refined Kano

\begin{tabular}{|c|c|c|c|c|c|c|}
\hline No & Attribute Code & Attribute Needs & $\begin{array}{c}\text { Kano } \\
\text { Category }\end{array}$ & $\begin{array}{l}\text { Strong / } \\
\text { Weak } \\
\text { Attribute }\end{array}$ & $\begin{array}{l}\text { Refined } \\
\text { Kano } \\
\text { Category }\end{array}$ & Recommendation \\
\hline 1 & Ease of Use 1 & Application provide easy features to use & $\begin{array}{c}\text { One } \\
\text { Dimensional }\end{array}$ & Strong & $\begin{array}{l}\text { High Value } \\
\text { Added }\end{array}$ & Prioritized \\
\hline 2 & Ease of Use 2 & Application is easy to understand & $\begin{array}{c}\text { One } \\
\text { Dimensional }\end{array}$ & Strong & $\begin{array}{l}\text { High Value } \\
\text { Added }\end{array}$ & Prioritized \\
\hline 3 & Ease of Use 3 & Application is easy to operate every time & $\begin{array}{c}\text { One } \\
\text { Dimensional }\end{array}$ & Strong & $\begin{array}{l}\text { High Value } \\
\text { Added }\end{array}$ & Prioritized \\
\hline 4 & Ease of Use 4 & Application can be accessed easily & $\begin{array}{c}\text { One } \\
\text { Dimensional }\end{array}$ & Strong & $\begin{array}{l}\text { High Value } \\
\text { Added }\end{array}$ & Prioritized \\
\hline 5 & $\begin{array}{l}\text { Information } \\
\text { Quality } 1\end{array}$ & Application provide clear information & $\begin{array}{c}\text { One } \\
\text { Dimensional }\end{array}$ & Strong & $\begin{array}{l}\text { High Value } \\
\text { Added }\end{array}$ & Prioritized \\
\hline 6 & $\begin{array}{l}\text { Information } \\
\text { Quality } 2\end{array}$ & $\begin{array}{l}\text { Application provide reminder } \\
\text { notification }\end{array}$ & $\begin{array}{c}\text { One } \\
\text { Dimensional }\end{array}$ & Weak & $\begin{array}{l}\text { Low Value } \\
\text { Added }\end{array}$ & Held \\
\hline 7 & $\begin{array}{l}\text { Information } \\
\text { Quality } 3\end{array}$ & Application provide tutorial notification & $\begin{array}{c}\text { One } \\
\text { Dimensional }\end{array}$ & Weak & $\begin{array}{l}\text { Low Value } \\
\text { Added }\end{array}$ & Held \\
\hline 8 & $\begin{array}{l}\text { Information } \\
\text { Quality } 4\end{array}$ & $\begin{array}{l}\text { Application provide rating and review } \\
\text { column }\end{array}$ & $\begin{array}{c}\text { One } \\
\text { Dimensional }\end{array}$ & Weak & $\begin{array}{l}\text { Low Value } \\
\text { Added }\end{array}$ & Held \\
\hline 9 & Payment Method 1 & $\begin{array}{l}\text { Application provide an easy payment } \\
\text { method }\end{array}$ & $\begin{array}{c}\text { One } \\
\text { Dimensional }\end{array}$ & Strong & $\begin{array}{l}\text { High Value } \\
\text { Added }\end{array}$ & Prioritized \\
\hline 10 & Payment Method 2 & $\begin{array}{l}\text { Application provide promo features that } \\
\text { are integrated automatically with } \\
\text { payment features }\end{array}$ & $\begin{array}{c}\text { One } \\
\text { Dimensional }\end{array}$ & Strong & $\begin{array}{l}\text { High Value } \\
\text { Added }\end{array}$ & Prioritized \\
\hline 11 & Payment Method 3 & $\begin{array}{l}\text { Application provide refund and } \\
\text { cancellation feature }\end{array}$ & $\begin{array}{c}\text { One } \\
\text { Dimensional }\end{array}$ & Strong & $\begin{array}{l}\text { High Value } \\
\text { Added }\end{array}$ & Prioritized \\
\hline 12 & $\begin{array}{l}\text { Application Design } \\
1\end{array}$ & Attractive application interface & $\begin{array}{c}\text { One } \\
\text { Dimensional }\end{array}$ & Strong & $\begin{array}{l}\text { High Value } \\
\text { Added }\end{array}$ & Prioritized \\
\hline 13 & $\begin{array}{l}\text { Application Design } \\
2\end{array}$ & Application display Is simple & $\begin{array}{c}\text { One } \\
\text { Dimensional }\end{array}$ & Strong & $\begin{array}{l}\text { High Value } \\
\text { Added }\end{array}$ & Prioritized \\
\hline 14 & $\begin{array}{l}\text { Application Design } \\
3\end{array}$ & Application provide reschedule feature & $\begin{array}{c}\text { One } \\
\text { Dimensional }\end{array}$ & Strong & $\begin{array}{l}\text { High Value } \\
\text { Added }\end{array}$ & Prioritized \\
\hline 15 & Responsiveness 1 & $\begin{array}{l}\text { Application provide responsive customer } \\
\text { service }\end{array}$ & $\begin{array}{c}\text { One } \\
\text { Dimensional }\end{array}$ & Strong & $\begin{array}{l}\text { High Value } \\
\text { Added }\end{array}$ & Prioritized \\
\hline 16 & Responsiveness 2 & $\begin{array}{l}\text { Application provide variety options } \\
\text { (travel partners and routes) }\end{array}$ & $\begin{array}{c}\text { One } \\
\text { Dimensional }\end{array}$ & Weak & $\begin{array}{l}\text { Low Value } \\
\text { Added }\end{array}$ & Held \\
\hline 17 & $\begin{array}{l}\text { Security \& Privacy } \\
1\end{array}$ & $\begin{array}{l}\text { Application can be protected from } \\
\text { unwanted access }\end{array}$ & $\begin{array}{c}\text { One } \\
\text { Dimensional }\end{array}$ & Weak & $\begin{array}{c}\text { Low Value } \\
\text { Added }\end{array}$ & Held \\
\hline 18 & $\begin{array}{l}\text { Security \& Privacy } \\
2\end{array}$ & Application can store user data & $\begin{array}{c}\text { One } \\
\text { Dimensional }\end{array}$ & Weak & $\begin{array}{c}\text { Low Value } \\
\text { Added }\end{array}$ & Held \\
\hline 19 & Portability 1 & $\begin{array}{l}\text { Application can be use on various } \\
\text { devices }\end{array}$ & $\begin{array}{c}\text { One } \\
\text { Dimensional }\end{array}$ & Weak & $\begin{array}{c}\text { Low Value } \\
\text { Added }\end{array}$ & Held \\
\hline 20 & Portability 2 & Application use less storage memory & $\begin{array}{c}\text { One } \\
\text { Dimensional }\end{array}$ & Weak & $\begin{array}{l}\text { Low Value } \\
\text { Added }\end{array}$ & Held \\
\hline 21 & Maintainability 1 & $\begin{array}{l}\text { System can be updated when failure } \\
\text { occurs }\end{array}$ & $\begin{array}{c}\text { One } \\
\text { Dimensional }\end{array}$ & Strong & $\begin{array}{l}\text { High Value } \\
\text { Added }\end{array}$ & Prioritized \\
\hline 22 & Maintainability 2 & $\begin{array}{l}\text { Application provide information about } \\
\text { causes of errors in the system }\end{array}$ & $\begin{array}{c}\text { One } \\
\text { Dimensional }\end{array}$ & Strong & $\begin{array}{l}\text { High Value } \\
\text { Added }\end{array}$ & Prioritized \\
\hline
\end{tabular}

\section{4) Kano Model}

In planning a product or service, it is necessary to make a list of products or services that will make customers feel satisfied. Kano Model is a method used to identify the attributes of a product or service based on customer satisfaction. Then the results that have been obtained, are categorized to get an understanding of customer needs (Lee, Lin, \& Wang, 2011). There are 6 types of quality attributes that lead to customer satisfaction and dissatisfaction, namely attractive, one-dimensional, must be, indifferent, reverse and questionable attributes [3].

\section{5) Refined Kano Model}

The definition of quality attribute categories according to Refined Kano, makes it possible to make higher quality decisions based on importance level. Following are the application of Refined Kano [4] :

a. Highly Attractive Attribute

Is a quality attribute that represents an effective way to attract potential customers and become a competitive advantage if implemented. This attribute will increase satisfaction if implemented. However, it will not cause dissatisfaction if it is not implemented.

b. Less Attractive Attribute

Is an attribute of quality that can be reduced if there are considerations based on certain factors. This attribute will increase satisfaction if implemented. However, it will not cause dissatisfaction if it is not implemented.

c. High Value Added Attribute

Is a quality attribute that contributes high to customer satisfaction. Therefore, it can increase revenue. This This attribute will increase satisfaction if implemented. However, this attribute will reduce satisfaction if it is not implemented.

d. Low Value Added Attribute

Is a quality attribute that have low contribution to customer satisfaction so that, its implementation can be considered based on certain factors. This attribute will 
The $1^{\text {st }}$ International Conference on Business and Engineering Management (IConBEM)

February $1^{\text {st }} 2020$, Institut Teknologi Sepuluh Nopember, Surabaya, Indonesia

increase satisfaction if implemented also, it will reduce satisfaction if not implemented

e. Critical Attribute

Is an attribute of quality that must be provided because it is very important for customers. This attribute does not have a big effect on increasing satisfaction if implemented also, it can reduce satisfaction if not implemented.

f. Necessary Attribute

It is an attribute of quality to avoid dissatisfied customers. Implementation of this attribute does not need to be prioritized. However, it must remain so that customer satisfaction is maintained.

g. Potential Attribute

Is an attribute of quality that gradually becomes aninteresting attribute. Implementation of this attribute does not need to be prioritized because it has no effect on customer satisfaction. However, it still has to be exist because it has the potential to be an attractive attribute.

h. Care Free Attribute

Is an attribute of quality that does not need to be offered because of cost considerations. Implementation of this attribute has no effect on customer satisfaction so the company can ignore this attribute.

\section{6) Fuzzy Refined Kano}

The traditional Kano Model Questionnaire requires answers in the range given. However, human thought is very complex, subjective and uncertain. This can be interpreted that when the respondent gives an answer, the respondent is usually not able to express of each questionnaire question entirely using a scale. The difference between traditional questionnaires and Kano Fuzzy allows respondents to give a single answer, while Fuzzy questionnaires provide a more flexible approach that allows respondents to answer according to their own criteria. Therefore, the use of the Fuzzy questionnaire shows a better understanding of what consumers actually think. The advantage of using the Fuzzy Kano questionnaire is that the data analysis is more valid.

The main advantages of Fuzzy Refined Kano is reducing subjectivity issues, thus making the evaluation process more robust and consistent. However, the disadvantages of this model are that it is more difficult to calculate. [1].

\section{B. Measuring Instrument Design}

This stage is the process for designing a measuring instrument that will be used in this research, which starts from gathering Voice of Customer using depth interviews to determine the number of samples and sampling techniques.

\section{Identification of Attributes Needs}

Identification of attributes needs that are considered by potential travel aggregator application users with intensive interviews with several respondents to find out the respondents perspective (depth interview).

D. Grouping Attributes Needs using Affinity Diagrams

This stage is carried out after completing the identification phase of attributes needs by classifying attributes needs based on the dimensions of Electronic Service Quality using affinity diagrams to facilitate data processing and analysis of data results.

\section{E. Operationalization of Variables}

This stage is carried out after completing the identification phase of attributes needs by classifying attributes needs based on the dimensions of Electronic Service Quality using affinity diagrams to facilitate data processing and analysis of data results.

\section{F. Attribute Encoding}

At this stage, coding of each indicator that has been determined based on the dimensions.

\section{G. Questionnaire Design}

Questionnaire is one technique to collect data by giving questions both verbally or in writing to respondents using 2 questionnaires namely Electronic Service Quality questionnaire and Fuzzy Kano questionnaire so that criteria are needed that can become respondents qualifications. Questionnaires must be filled in by appropriate respondents so that appropriate criteria for respondent are needed to fill in the questionnaire.

Electronic Service Quality Questionnaire is a questionnaire that is used to explore attributes that are considered important based on potential users so that they can determine the importance of an attribute based on the assessment that has been given.

Fuzzy Kano Questionnaire is a questionnaire used to measure the level of satisfaction that will occur if the attribute is implemented by categorizing the attributes based on the 6 categories of Kano.

H. Content Validity

Content validity is the validity process through analysis by expert judgement to its content that illustrates how well the dimensions are.

\section{Pretest}

Pretest is an initial test used to identify respondents understanding of the questions given with a sample size of 30 respondents to find out what needs to be improved in the questionnaire before distributing the questionnaire.

Pretest normality test needs to be done before testing the construct validity. The construct validity is to show the compatibility of the results obtained with the theory so that the questionnaire is feasible to be distributed because the questions asked are proven to provide valid information.

J. Determination of The Number of Samples and Sampling Technique

In distributing questionnaires to prospective users, the sampling technique used in this study is the non probability sampling technique with the type of judgment sampling.

\section{$K$. Data Processing}

Reliability tests were carried out on each dimension on the Electronic Service Quality and Fuzzy Kano questionnaires. Reliability tests were carried out on each dimension on the Electronic Service Quality questionnaire and the Fuzzy Kano questionnaire.

In this study, the reliability test was carried out Calculated using the Alpha Cronbach method in the IBM SPSS Statistics software for the Electronic Service Quality questionnaire and using the triangulation method for the Kano Fuzzy questionnaire.

Electronic Service Quality questionnaire data processing will produce a calculation of the value of customer interests 
The $1^{\text {st }}$ International Conference on Business and Engineering Management (IConBEM)

February $1^{\text {st }} 2020$, Institut Teknologi Sepuluh Nopember, Surabaya, Indonesia

to the application by calculating the average value of interest. Through the level of importance value test on the Electronic Service Quality questionnaire, it can be identified attributes that are considered important or expected by potential users of travel aggregator applications. The attributes are classified as strong and weak attributes based on average values. Strong and weak attributes indicate strengths and weaknesses of the importance of implementing attributes according to prospective users. The value that above average can be said meet customer expectations so it is a strong attribute. Conversely, the value below average can be interpreted as not meet customer expectations so it is a weak attribute. The results of the Electronic Service Quality calculation can determine the level of service quality of the application provided satisfactory or not [4].

The average value in this study is 7.2116. Attribute values that are above the average can be classified as strong attributes, while attribute values that are below the average can be classified as weak attributes. The strong attribute category defines the importance of attribute implementation, while the weak attribute class defines the importance of less implementation.

Data Processing is also carried out on the Kano Fuzzy questionnaire. Through the Kano category on the Kano Fuzzy questionnaire, satisfaction levels can be measured if the attributes are implemented according to potential users. Processing of the Fuzzy Kano model questionnaire begins with the classification of respondents' answers to the functional and dysfunctional questionnaire. Classification of answers is done by using the Kano evaluation table. The next step is determining the Kano category using Blauth's Formula to identify the Kano category for each attribute needs by adding up the results of each category.

L. Integration of Fuzzy Electronic Service Quality and Fuzzy Refined Kano

At this stage an integration is made between the results obtained from the processing of the Electronic Service Quality questionnaire and the Fuzzy Kano model with the Refined Kano dimension. Attractive (A) categorized attribute with strong interest value category is translated as highly attractive attribute, while attribute with weak interest value category is translated as less attractive attribute. One dimensional (O) categorized attribute with strong interest value category is translated as high value added attribute, while attribute with weak interest value category is translated as low value added attribute. Must-be (M) categorized attribute with strong importance value category is translated as critical attribute, while attribute with weak interest value category is translated as necessary attribute. Indifferent (I) categorized attribute with strong interest value category is translated as potential attribute, whereas attribute with weak interest value category is translated as care free attribute [4].

Determination of True Customer Needs is based on the attributes of the recommended needs with the category of strong attributes as True Customer Needs.

\section{RESULT AND DISCUSSION}

There are 22 attributes with 2 dimensional limitations namely portability \& maintainability and 6 dimensions of Electronic Service Quality namely ease of use, information quality, payment method, application design, responsiveness and security \& privacy.

Electronic Service Quality questionnaire data processing produce importance value. Questionnaire data for each attribute that has been declared reliable is then averaged to produce the importance value of each attribute. These attributes categorizes as strong and weak attributes from the processing of Electronic Service Quality questionnaire data.

Fuzzy Kano questionnaire data processing is used to obtain the categories of each attribute needs by combining the results of the normalization of functional and dysfunctional question questionnaires using Blauth's Formula. Table 3.1 is the result of Electronic Service Quality questionnaire data processing which produces 14 strong attributes and 8 weak attributes.

Strong attributes have importance values above the average value. In this study, there were 14 strong attributes with importance values above the average. Weak attributes have below average importance. In this study, there were 8 weak attributes with importance values below the average.

There are 22 attributes with one dimensional Kano category. The level of satisfaction of potential users will decrease if the attribute is not implemented but the satisfaction of potential users will increase if attributes implemented. These results are categorized as Refined Kano category such as less attractive, highly attractive, low value added, high value added, necessary, critical, potential dan care free to determine the recommended actions that need taken in developing travel aggregator application.

Based on the results of the integration between the Electronic Service Quality questionnaire and Fuzzy Kano questionnaire, there are 8 attributes with low value added category such as application provide reminder notification, application provide tutorial notification, application provide rating and review column, application provide variety options (travel partners and routes), application can be protected from unwanted access, application can store user data, application can be use on various devices, application use less storage memory so this attributes are recommended not to be implemented because attributes with low value added are not categorized as True Customer Needs.

There are 14 attributes with high value added category such as application provide easy features to use, application is easy to understand, application is easy to operate every time, application can be accessed easily, application provide clear information, application provide an easy payment method, application provide promo features that are integrated automatically with payment features, attractive application interface, application display is simple, application provide reschedule feature, application provide responsive customer service, system can be updated when failure occurs, application provide information about causes of errors in the system. 
The $1^{\text {st }}$ International Conference on Business and Engineering Management (IConBEM)

February $1^{\text {st }} 2020$, Institut Teknologi Sepuluh Nopember, Surabaya, Indonesia

Satisfaction will decrease if this attributes are not implemented but satisfaction will increase if this attributes is implemented.

Based on the integration of the Refined Kano category with the results of the processing Electronic Service Quality questionnaire and the Fuzzy Kano questionnaire, there are 14 attributes that are become recommendation to Travel Aggregator to be prioritized so these are specified as True Customer Needs. This is based on the attribute needs that are included in the priority category in the travel aggregator application. Attributes with these recommendations are considered to represent the interests and expectations of potential users for the development of travel aggregator applications.

\section{CONCLUSION}

Based on the objectives of the study, the following conclusions are obtained :

1. There are 22 needs attributes identified based on 8 dimensions of Electronic Service Quality, namely ease of use, information, payment methods, application design, responsiveness, security and privacy, portability and maintainability.

2. Based on Electronic Service Quality questionnaire data processing, there are 14 strong attributes that defined from the importance of implementing attributes in the travel aggregator application and 8 weak attributes that defined from the less importance of implementing the attributes in the travel aggregator application

3. Based on the results of the integration of Fuzzy Electronic Service Quality and Fuzzy Refined Kano, obtained 14 attributes needs included in the high value added category and 8 attributes needs included in the low value added category.

4. Based on the integration results, there are 8 attributes that are recommended to be held and 14 attributes of True Customer Needs that are recommended to be prioritized such as features easy to use, application is easy to understand, application is easy to operate at every time, application is easy to access, application has clear information, application has an easy payment method, application has a promo feature that is integrated automatically with the payment feature, application has refund and cancellation features, application interface is attractive, application interface is simple, application has reschedule feature, responsive customer service (live chat), can overcome error that can slow down application performance and application has information about the cause of errors in the system due to connection. These attributes need to be considered in order to attract potential users.

5. Determination of attributes with the integration of Fuzzy Electronic Service Quality and Fuzzy Refined Kano produces 14 attribute needs that become True Customer Needs.

\section{ACKNOWLEDGMENTS}

Based on the research that has been done, the researcher suggest to do a further research and having a deeper understanding of Fuzzy theory when identifying the attributes of needs that can represent the travel aggregator application.

\section{REFERENCES}

[1] P.-L. Hsieh, T.-M. Yeh, and J.-E. Chen, "Integrating Fuzzy SERVQUAL into Refined Kano Model to Determine the Critical Service Quality Attributes of Chain Restaurants," Rev. Integr. Bus. Econ. Res., vol. 4, no. 4, p. 142, 2015.

[2] C. Filho and X. Boucher, "ScienceDirect 7th Industrial ProductService Systems Conference-PSS, industry transformation for sustainability and business A fuzzy SERVQUAL based method for evaluated of service quality in the hotel industry," Procedia CIRP, vol. 30, pp. 433-438, 2015, doi: 10.1016/j.procir.2015.02.140.

[3] Utsman, "Validitas Dan Reliabilitas Untuk Mengevaluasi Mutu Penelitian," J. Unnes, no. October, 2017.

[4] C. C. Yang, "The Refined Kano's Model and Its Application," Total Qual. Manag. Bus. Excell., vol. 16, no. 10, pp. 1127-1137, 2005, doi: $10.1080 / 14783360500235850$. 